\title{
Tagabo Volcanic Ash as Cement Replacing Materials
}

\author{
Mutasim A. Ahmedai ${ }^{1, *}$, Salih A. M. Ahmed ${ }^{2}$, Yousif H. Ahmed ${ }^{3}$, and El-Sharif M. Ibrahiem ${ }^{1}$ \\ 1 Civil Engineering Department, University of Nyala, Nyala, Sudan \\ 2 Civil Engineering Department, Sudan University of Science and Technology, Khartoum, Sudan \\ 3 Civil Engineering Department, University of Khartoum, Khartoum, Sudan \\ * Corresponding author: Mutasim A. Ahmedai (e-mail: mutasimahmedai2014@gmail.com).
}

Article history: Received 14 March 2020, Received in revised form 4 November 2020, Accepted 11 November 2020

$$
\begin{aligned}
& \text { المستخلص تهدف هذه الورقة إلى تقييم الخصائص البوزولانية للرماد البركاني تم الحصول عليها من جبال تقابو من ولاية شمال دارفور في غرب السودان }
\end{aligned}
$$

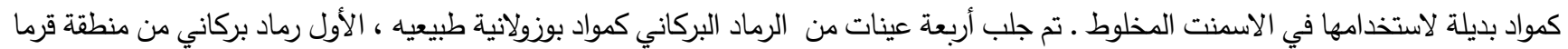

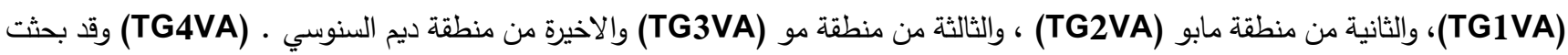

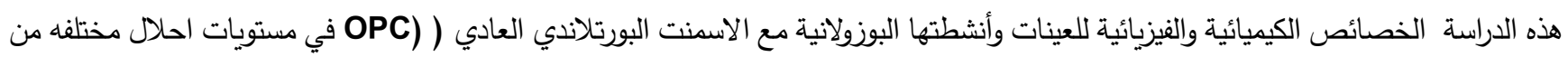

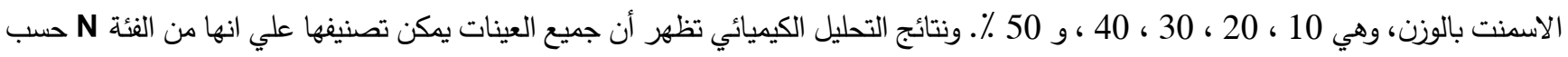

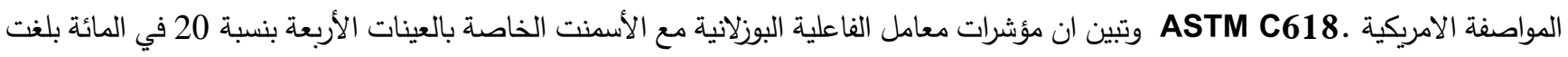

$$
\begin{aligned}
& \text { 75 ،84 ، } 89 \text { و } 83 \text { في المائة علي التوالي. تشير هذه النتائج إلى ان عينات البوزولانا من جبال تقابو هي مواد من المحتمل استخدامها في الاسمنت }
\end{aligned}
$$

$$
\text { الكلمات المفتاحية: البوزولانا ، الأسنت المخلوط ، الرماد البركاني ، جبال تقابو -شمال دارفور }
$$

\begin{abstract}
This paper aims to assess the pozzolanic characteristics of the volcanic ash obtained from Jebal Tagabo (Tagabo Mountains) in western Sudan (North Darfur State) as potential Supplementary Cementitious Materials for use in blended cement and concrete. Four natural Pozzolanic materials samples have been obtained; the first is volcanic ash from the Garma region (TG1VA), the second from the Mabo region (TG2VA), the third from the Mawo region (TG3VA) and the last from the Daim Sanosi region (TG4VA). This study has investigated the chemical and physical characteristics of the samples and their pozzolanic activities with Ordinary Portland cement (OPC) at different substitution levels of cement by weights, which are 10,20,30,40, and 50\%. And the results of chemical analysis show that all samples can be classified as Class $\mathrm{N}$ according to the American standard ASTM C618. The strength activity indices of the four samples at $20 \%$ level were found to be $75,84,89$, and $83 \%$ respectively. These results indicate that the Jebal Tagabo Pozzolans are potential supplementary cementitious materials for use in blended cement.
\end{abstract}

Keywords: pozzolanic reactivity, Blended cements, volcanic ash, Jebal Tagabo -Darfur.

\section{INTRODUCTION}

Cement is an important material used in the construction field. The constant search for additional materials are required to replace a part of the cement in the mixtures or to reduce its quantities, thus reducing carbon dioxide emissions, transportation and energy with a mix or to improve the rate of gain in strength, durability, and its others properties.

Research had been carried out on the use of cement replacement material (SCMs) that can be blended with Portland cements like fly ash (FA), volcanic ash (VA), blast furnace slag (BFS), etc. 
[1-6]. The FA and VA are pozzolanic materials, because of their reaction with lime (calcium hydroxide) liberated during the hydration of cement. Amorphous silica present in the pozzolanic materials combines with lime and forms cementitious materials ASTM C618 (2005) [7].

The Natural pozzolans are those materials which do not require any further treatment apart from grinding to react with lime F.MASSAZZA (1976) [8].

In Sudan, natural pozzolanas have been reported by Mamoun, (2004) [9] who characterized some natural pozzolana in Sudan such as obsidian deposits (Sabaloka-Northern Khartoum), Natural burnt clay (Southern Bayouda) and Diatomite deposits (Gregrieb Gezira). He determined their pozzolanic reactivity through compressive strength, and factors affecting the compressive strength of lime pozzolan mortar. He also reported the existence of volcanic ash in Marra Mountain, Meidoub Mountains and Tagabo in Darfour with no detailed information or characterization for these deposits. Elsharif M. I (2014) [10] has investigated Jebel Marra Volcanic Ash as SCM for Use in Blended Cements.

Volcanic ash (VA) is a natural pozzolanic material that is available in many volcanic areas in the Sudan and is inexpensive. It only needs to be crushed and grinded .The use of these volcanic materials can transform them into natural resources for the production of low-cost building materials and environmentally friendly with acceptable strength and durability characteristics, that can contribute to the sustainable development.

The partial replacement of Portland cement by volcanic ash in mortars and concrete, when available, may be better in practice and lead to an economic solution especially in place like Northern Darfur state. This paper aims to assess the pozzolanic characteristics of the volcanic ash obtained from Jebal Tagabo (Tagabo Mountains) in the northern Darfour state; it's located in the Mara and Meidoub mountain series at $125 \mathrm{Km}$ from $\mathrm{Al}$ Fasher town in Northern east direction. It is characterized by the volcanic field which is considered as potential SCMs for use in blended cement and concrete.

\section{MATERIALS AND METHODS}

\section{A. Materials}

\section{Cement}

Ordinary Portland cement (OPC) from Atbara Cement Company.

\section{Sand}

River sand from Wadi Nyala was washed, dried, sieved and graded from $90 \mu \mathrm{m}$ to $1.18 \mathrm{~mm}$ according to ASTM: C 778 - 02[11] have been used in the present study.

\section{Volcanic ash (VA)}

Four natural Pozzolanic samples were brought from Jebal Tagabo. Sample one is Tagabo volcanic ash from the Garma region (TG1VA) at coordinates ( $\mathrm{N} \mathrm{14^{ \circ }} 27^{\prime} 40.6^{\prime \prime}$, E 25우 $39^{\prime} 54.9^{\prime \prime}$ ), sample two is Tagabo volcanic ash from the Mabo region (TG2VA) at coordinates ( $14^{\circ} 34^{\prime} 39.9^{\prime \prime}$, E $\left.25^{\circ} 44^{\prime} 02.1^{\prime \prime}\right)$, sample three is Tagabo volcanic ash from the Mawo region (TG3VA) at coordinates (N $14^{\circ} 34^{\prime} 33^{\prime \prime}$, E $25^{\circ} 43^{\prime} 54.42^{\prime \prime}$ ) and sample four is Tagabo volcanic ash from the Daim Sanosi region (TG4VA) at coordinates ( $14^{\circ} 28^{\prime} 14.68^{\prime \prime}$, E $25^{\circ}$ $\left.33^{\prime} 44.37^{\prime \prime}\right)$.The four samples were grounded, sieved and then characterized using chemical and physical analysis according to ASTM C311-02 [12].

\section{Water}

Water from the public main supply in Wadi Nyala was used for the mixing and the curing of the mortar cubes.

\section{B. Methods}

\section{Grinding of the pozzolanic materials}

When the fineness of the pozzolanic materials affecting the reactivity of the blended cement, to achieve desired fineness, local made Ball mill for laboratory purposes, about one kilogram capacity was used, desired fineness can be achieved depending on operating time.

\section{Preparation of control and blended cement mortar}

A control mix was prepared in $50 \mathrm{~mm}$ cubes moulds (area of face $25 \mathrm{~cm} 2$ ). The control mix was 
produced using OPC only as binder with the proportions of materials one part of cement to 2.75 parts of graded standard sand by weight and water-cement ratio of 0.485 such as to produce a flow table of $110 \pm 5$ as specified in ASTM C 109/C $109 \mathrm{M}$ - 02[13]. The proportions of the different mixes with blended cement used in this study are listed in Table (1). As specified in ASTM C 311 02[12] to produce the same flow of the control mixture \pm 5 .

The Four samples were incorporated in the mixes at $10 \%, 20 \%, 30 \%, 40 \%$, and $50 \%$ replacement levels, the blended mixes (OPC/ xi) were made with the same workability (flow of the control mixture \pm 5 ) as needed in practice. Where: xi represent the four samples that brought from Jebal Tagabo (TG1VA, TG2VA, TG3VA \& TG4VA). Changes in mortar properties were investigated related to different types of Pozzolanic samples (xi) under the study where xi represents TG1VA, TG2VA, TG3VA and TG4VA.

\section{Mixing and casting}

The fresh mortar was mixed and 12 cubes for each mix (total of 300 cubes) were casted as required by ASTM C 109/C 109M - 02[13]. The specimens were de-molded after at least 24 hours and immersed into the curing tank until testing.

\section{RESULTS AND DISCUSSION}

\section{A. Chemical properties}

Results of the chemical analysis of TG1VA, TG2VA, TG3VA and TG4VA are shown in Table (2). They show that the sum of principal oxides of Silica ( $\mathrm{SiO} 2)$, Alumina (Al2O3) and Iron (Fe2O3) are within the limits (at least $70 \%$ ) of the ASTM C 618 - 05 [7]. They also conform to the specification of loss on ignition $\leq 10 \%$, SO3 $\leq 4 \%$, and moisture content $\leq 3$.

\section{B. Physical and mechanical properties of pozzolanic materials}

Table (3) enlists physical properties such as fineness and mechanical properties of mortars incorporating the pozzolanic samples such as strength activity index and water requirement. All natural pozzolan specimens are complied with class (N) of the ASTM C $618-05$ [7].

\section{Water consistency and setting time limits}

The results presented in Figure (1), indicated that addition of Tagao volcanic ash samples improve Consistency and workability of pozzolanic cement mixture. This may be attributed to higher fineness and surface area of pozzolans particles. Most natural pozzolanas tend to increase the water requirement in the normal consistency test as a result of their micro porous character and high surface area ACI 232.1R (2000) [14]. Also in Figure (2), addition of Tagabo volcanic ash retarded the initial and final setting time. This in agreement with Ramezanianpour et al [15], who reported that the setting time of cements containing various natural pozzolans are extended with level of replacement of the cement.

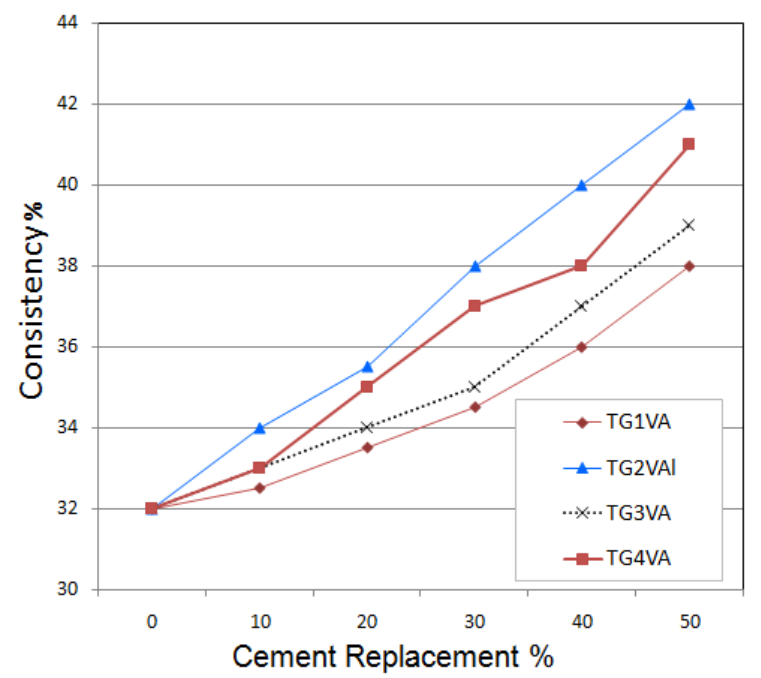

Fig. 1: Effect of Tagabo pozzolans samples in the consistency of the Portland cement.

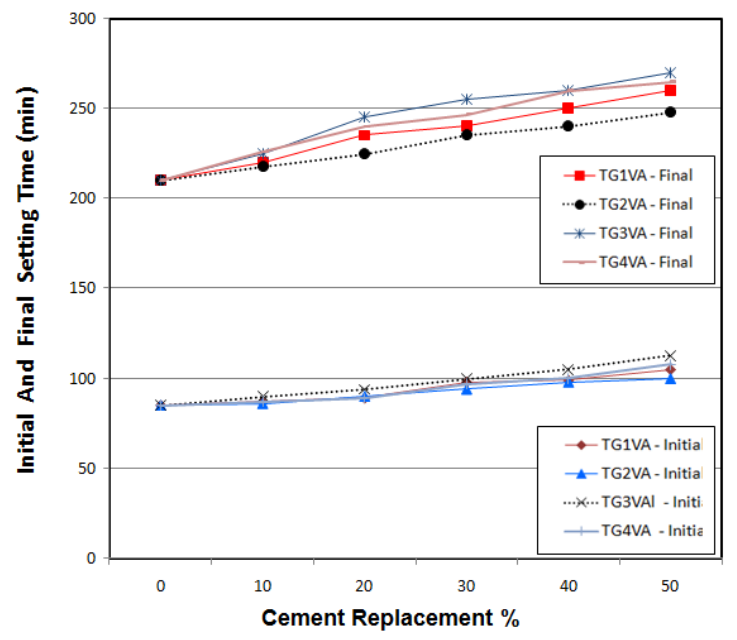

Fig. 1: Effect of Tagabo pozzolans samples in the setting time of the Portland cement. 
TABLE 1: MORTAR MIXES PROPORTIONS (RATIO BY WEIGHT)

\begin{tabular}{|c|c|c|c|c|}
\hline Mix ref. & OPC & $\begin{array}{c}\text { Jebel Tagabo } \\
\text { Pozzolanic samples( xi ) }\end{array}$ & Sand & Water \\
\hline Control (CTR) & 1 & 0 & 2.75 & 0.485 \\
\hline OPC/ 0.1 & 0.9 & 0.1 & 2.75 & \multirow{5}{*}{$\begin{array}{l}\text { water required for flow } \pm 5 \text { of } \\
\text { control mixture }\end{array}$} \\
\hline $\mathrm{OPC} / 0.2$ & 0.8 & 0.2 & 2.75 & \\
\hline $\mathrm{OPC} / 0.3$ & 0.7 & 0.3 & 2.75 & \\
\hline OPC/ 0.4 & 0.6 & 0.4 & 2.75 & \\
\hline OPC/ 0.5 & 0.5 & 0.5 & 2.75 & \\
\hline
\end{tabular}

TABLE 2: CHEMICAL PROPERTIES OF OPC, TG1VA, TG2VA, TG3VA AND TG4VA

\begin{tabular}{|c|c|c|c|c|c|c|c|c|c|}
\hline \multirow{2}{*}{ Materials } & \multicolumn{9}{|c|}{ Chemical Composition (\%) } \\
\hline & $\mathrm{SiO} 2$ & $\mathrm{Al} 2 \mathrm{O} 3$ & $\mathrm{Fe} 2 \mathrm{O} 3$ & $\mathrm{CaO}$ & $\mathrm{MgO}$ & $\mathrm{SO} 3$ & $\mathrm{~K} 2 \mathrm{O}$ & $\mathrm{Na} 2 \mathrm{O}$ & LOI \\
\hline OPC & 19.83 & 5.35 & 2.795 & 65.88 & 1.71 & 2.3 & 0.4 & -- & 2 \\
\hline TG1VA & 64.04 & 17.85 & 1.588 & 0.849 & 1.086 & 0.02 & 2.701 & 1.825 & 6.3 \\
\hline TG2VA & 61.31 & 18.29 & 2.425 & 0.972 & 1.558 & 0.18 & 4.645 & 2.372 & 4.6 \\
\hline TG3VA & 64.80 & 20.10 & 1.77 & 0.596 & 0.790 & 0.18 & 1.384 & 1.171 & 6.7 \\
\hline TG4VA & 71.13 & 14.76 & 1.756 & 0.539 & 1.359 & 0.11 & 1.596 & 0.905 & 3.8 \\
\hline \multicolumn{4}{|c|}{ Test } & TG1VA & TG2VA & TG3VA & TG4VA & \multicolumn{2}{|c|}{$\begin{array}{c}\text { ASTM C618-05 } \\
\text { Class N Pozzolan }\end{array}$} \\
\hline \multicolumn{4}{|c|}{$\begin{array}{l}\text { Fineness (Amount retained when wet-sieved on } 45 \\
\qquad \mu \mathrm{m} \text { sieve) } \%\end{array}$} & 12 & 18 & 14 & 18 & \multicolumn{2}{|c|}{34 (max.) } \\
\hline \multicolumn{4}{|c|}{ Strength Activity Index at 7 days, $\%$} & 83 & 91 & 88 & 88 & \multicolumn{2}{|c|}{75 (min.) } \\
\hline \multicolumn{4}{|c|}{ Strength Activity Index at 28 days, $\%$} & 75 & 84 & 89 & 83 & \multicolumn{2}{|c|}{75 (min.) } \\
\hline \multicolumn{4}{|c|}{ Water requirement of control \% (max) } & 108 (max.) & 106 (max.) & 104 (max.) & 108 (max.) & \multicolumn{2}{|c|}{115 (max.) } \\
\hline
\end{tabular}

\section{Compressive strength results}

The compressive strength results of the TG1VA, TG2VA, TG3VA and TG4VA with replacement levels of $10 \%, 20 \%, 30 \%, 40 \%$ and $50 \%$ at various ages of curing time up to 90 days are presented in Figure (3), (4), (5) and (6) respectively. Clearly seen that the four samples contributes to the strength of mortars after 3 days of curing. However $20 \%$ addition of the four samples provided $75 \%$ and more than the control compressive strengths at 7 and 28 days as reported in table(3). These percentages additions met the ASTM C 618 - 05 [12] specifications. The compressive strength of the mortars containing 10 - $20 \%$ TG3VA and 10\% TG4VA pozzolans replacement were even higher than control mortar after 90 days. Lower strengths were obtained for those blends with higher substitution levels of Pozzolanas, so the compressive strength values decreases with increase in the substitution ratio of Pozzolanic samples used.

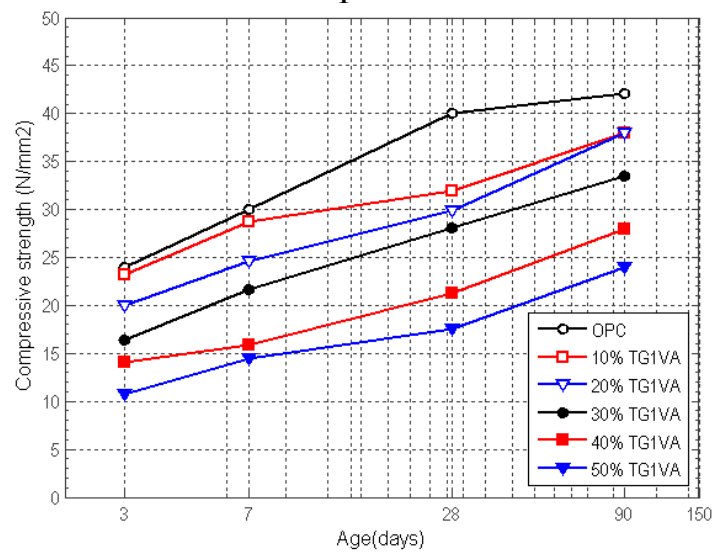

Fig. 2: Strength development of blended cement made with TG1VA Pozzolana

\section{E. Summary}

(1) The results of the chemical analysis are conforming to the ASTM C 618 - 05 [1]. 
(2) The samples of Tagabo natural pozzolans affect the consistency and setting time of the pastes. They led to an increase in the water demand and the setting time.

(3) The strength reactivity of Tagabo natural pozzolans samples with OPC at 7 and 28 days are provided $75 \%$ and more than the control strength complying to the ASTM C 618 - 05 [7] requirements.

(4) There is a need to investigate the long term engineering properties of these mixtures such as shrinkage and durability performance.

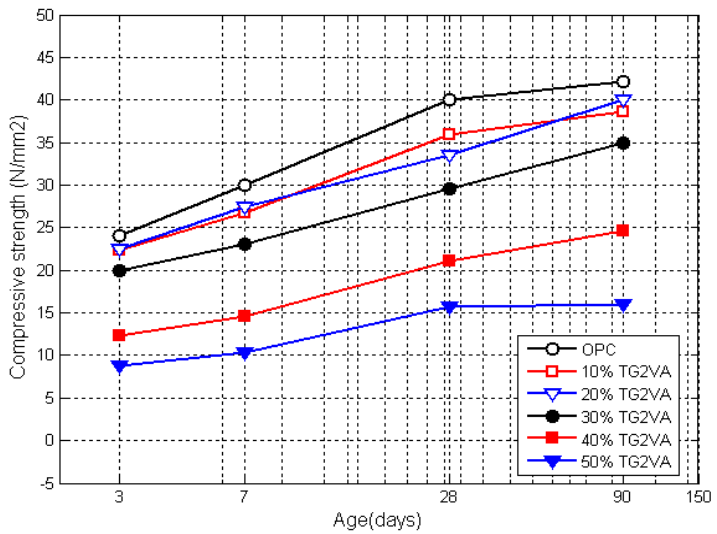

Fig. 3: Strength development of blended cement made with TG2VA Pozzolana

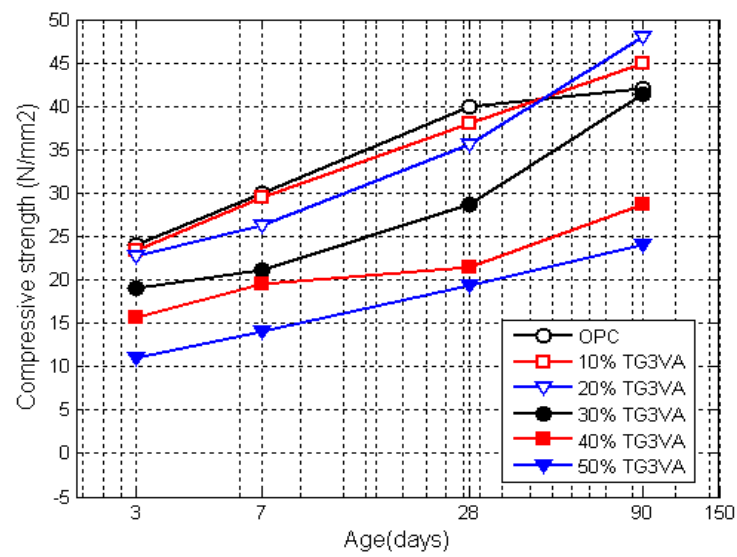

Fig. 5: Strength development of blended cement made with TG3VA Pozzolana

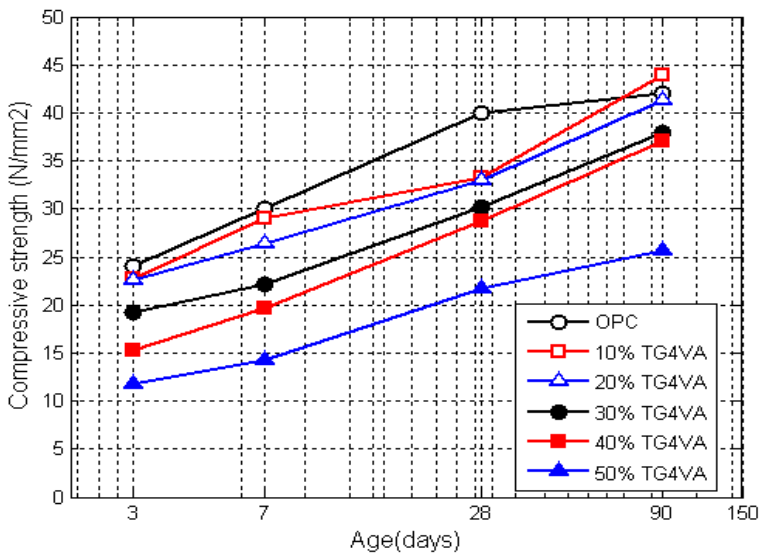

Fig. 6: Strength development of blended cement made with TG4VA Pozzolana

\section{CONCLUSIONS}

The evaluations of the chemical, physical and mechanical properties of the Tagabo pozzolans or mixtures incorporating them have revealed their compliance to Class N of ASTM C 618 - 05 [7] Specifications. This means they can be safely used as supplementary for OPC in the Northern Darfur area saving energy and money.

\section{REFERENCES}

[1] R.N. Swamy, Cement Replacement Materials, Concrete Technology and Design, vol. 3, Surrey University Press, Great Britain, 1986.

[2] K.M.A. Hossain, Properties of volcanic ash and pumice concrete, IABSE Rep. 80 (1999) 145-150.

[3] K.M.A. Hossain, Blended cement using volcanic ash and pumice, Cem. Concr. Res. 33 (10) (2003) 1601-1605.

[4] A. Bilodeau, V.M. Malhotra, High volume fly ash system: concrete solution for sustainable development, ACI Mater. J. 99 (1) (2000) 41-48.

[5] E.E. Berry, V.M. Malhotra, Fly ash for use in concrete-a critical review, J. of ACI 77 (8) (1980) 59-73.

[6] R.D. Hooton, Canadian use of ground granulated blast-furnace slag as a supplementary cementing material for enhanced performance of concrete, Canadian J. Civ. Eng. 27 (2000) 754-760.

[7] ASTM C 618 - 05, Standard Specification for Fly Ash or Raw or Natural Pozzolan for Use as a Mineral Admixture in Portland cement Concrete, American Society for Testing and Materials,

[8] F. Massazza, Chemistry of pozzolanic additions and mixed cements. Il Cemento 1, 3-38(1976)

[9] Mamoun, E.M. (2004) "Natural Pozzolanas in Sudan: characterization and factors affecting compressive strength of lime/pozzolana mortar", doctoral diss., University of Khartoum, Sudan.

[10] Elsharif M. Ibrahiem, Salih A. M. Ahmed (2014) "Evaluation of Jebel Marra Volcanic Ash as Supplementary Cementitious Material for Use in Blended Cements". IOSR Journal of Engineering (IOSRJEN) Vol. 04, Issue 03 (March. 2014), I | V2 | । PP 31-37.

[10] A/Ellatif Eltayeb, Mohamed Salih Elhadi (2014) "The Quality of Natural Pozzolanic Materials at Bayuda desert in Northern Sudan". IOSR Journal of Engineering (IOSRJEN) Vol. 04, Issue 04 (April. 2014), | |V7| | PP 08-14

[11] ASTM C 778 - 02. "Standard Specification for Standard Sand"

[12] ASTM C 311- 02 "Standard Test Methods for Sampling and Testing Fly Ash or Natural Pozzolans for Use in Portland-Cement Concrete"

[13] ASTM C 109/C 109M - 02"Standard Test Method for Compressive Strength of Hydraulic Cement Mortars (Using 2-in. or [50-mm] Cube Specimens)"

[14] Paul J. T. (2000)," Use of Raw or Processed Natural Pozzolanas in Concrete" ACI Committee 232

[15] A.A. Ramezanianpour, H. Rahmani, Durability of concretes containing two natural pozzolans as supplementary cementing materials, in 7th International Congress on Concrete, 8-10 July 2008, Dundee, UK. 